\title{
IRF4 Gene Rearrangement
}

National Cancer Institute

\section{Source}

National Cancer Institute. IRF4 Gene Rearrangement. NCI Thesaurus. Code C133495.

A molecular abnormality indicating rearrangement of the IRF4 gene. 